\title{
Pengaruh pH Awal dan Suhu selama Penyimpanan terhadap Stabilitas Ekstrak Pewarna Kulit Buah Jeruk Mandarin (Citrus reticulata) \\ The effect of Initial $\mathrm{pH}$ and temperature during storage on stability of pigment extract Mandarin orange peel (Citrus reticulata)
}

\author{
Alfridus Sandro Dacosta Perdisen, Ni Made Wartini*, Amna Hartiati \\ PS Teknologi Industri Pertanian, Fakultas Teknologi Pertanian, Universitas Udayana, Kampus Bukit \\ Jimbaran, Badung, Kode pos : 80361; Telp/Fax : (0361) 701801
}

Diterima 16 November 2021 / Disetujui 29 Desember 2021

\begin{abstract}
The orange peel of Mandarin oranges contains carotenoid compounds which have potential as natural yellow and orange dyes and also as a source of antioxidants. The dye obtained from Mandarin orange peel has unstable properties. The purpose of this study was to know the effect of initial $\mathrm{pH}$ and temperature during storage on the stability of the Mandarin orange peel dye extract and determine the best initial $p H$ and temperature during storage to maintain the stability of the Mandarin orange peel dye extract (Citrus reticulata). The experiment of this study used Completely Randomized Design with two factors. The first factor is initial $\mathrm{pH}$ consisting of three levels: $\mathrm{pH} 4,7$, and 10. The second factor is temperature during storage consisting of two levels: $4 \pm 3^{\circ} \mathrm{C}$ and $28 \pm 3^{\circ} \mathrm{C}$. The results showed that initial $\mathrm{pH}$ had significant effect $(P<0.01)$ on carotenoids, antioxidant capacity, brightness $\left(L^{*}\right)$, redness $\left(a^{*}\right)$, and yellowess $\left(b^{*}\right)$. The temperature during storage had significant effect on carotenoids, antioxidant capacity, brightness $\left(L^{*}\right)$, and yellowess ( $\left.b^{*}\right)$ but had not significant effect $(P>0.05)$ on redness $\left(a^{*}\right)$. The dye extract of Mandarin orange peel was more stable at the storage conditions of $\mathrm{pH} 7$ (neutral) and cold temperature $\left(4 \pm 3^{\circ} \mathrm{C}\right)$ during 4 weeks storage with decreased of carotenoids, antioxidant capacity, increase in brightness ( $\left.L^{*}\right)$, decrease in redness $\left(a^{*}\right)$, and decrease in yellowess $\left(b^{*}\right)$ successively was $42,96 \% ; 21,02 \% ; 26,36 \% ; 20,89$ dan 16,89\%.
\end{abstract}

Keywords: Mandarin orange peel extract, carotenoids, $p H$, temperature, color stability.

\section{ABSTRAK}

Kulit buah jeruk Mandarin berwarna orange mengandung senyawa karotenoid yang dapat berpotensi sebagai pewarna alami kuning, orange dan sebagai sumber antioksidan. Zat warna yang diperoleh dari kulit buah jeruk Mandarin memiliki sifat yang tidak stabil. Tujuan dari penelitian ini adalah mengetahui pengaruh $\mathrm{pH}$ awal dan suhu selama penyimpanan terhadap stabilitas ekstrak pewarna kulit buah jeruk Mandarin serta menentukan $\mathrm{pH}$ awal dan suhu selama penyimpanan terbaik untuk mempertahankan stabilitas ekstrak pewarna kulit buah jeruk Mandarin. Rancangan dalam penelitian ini menggunakan Rancangan Acak Lengkap dengan dua faktor. Faktor I adalah perlakuan $\mathrm{pH}$ awal yang terdiri dari tiga taraf yaitu $\mathrm{pH} 4,7$, dan 10. Faktor II adalah suhu selama penyimpanan yang terdiri dari dua taraf yaitu $4 \pm 3^{\circ} \mathrm{C}$ dan $28 \pm 3^{\circ} \mathrm{C}$. Hasil penelitian menunjukkan bahwa $\mathrm{pH}$ awal berpengaruh sangat nyata $(\mathrm{P}<0,01)$ terhadap total karoten, kapasitas antioksidan, nilai kecerahan $\left(\mathrm{L}^{*}\right)$, nilai kemerahan $\left(a^{*}\right)$, dan nilai kekuningan $\left(b^{*}\right)$. Suhu selama penyimpanan berpengaruh sangat nyata $(\mathrm{P}<0,01)$

*Korespondensi Penulis:

Email: md_wartini@unud.ac.id 
pada total karoten, kapasitas antioksidan, nilai kecerahan $\left(\mathrm{L}^{*}\right)$, dan nilai kekuningan $\left(\mathrm{b}^{*}\right)$ tetapi berpengaruh tidak nyata $(\mathrm{P}>0,05)$ pada nilai kemerahan $\left(\mathrm{a}^{*}\right)$. Ekstrak pewarna karotenoid kulit buah jeruk Mandarin paling stabil pada perlakuan $\mathrm{pH} 7$ (netral) dan suhu dingin $\left(4 \pm 3^{\circ} \mathrm{C}\right)$ selama 4 minggu penyimpanan, dengan persentase penurunan total karotenoid, penurunan kapasitas antioksidan, kenaikan nilai $\mathrm{L}^{*}$, penurunan nilai a*, dan penurunan nilai $b^{*}$ berturut-turut adalah sebesar $42,96 \% ; 21,02 \% ; 26,36 \% ; 20,89$ dan $16,89 \%$.

Kata kunci : Ekstrak kulit buah jeruk Mandarin, karotenoid, pH, suhu, stabilitas warna.

\section{PENDAHULUAN}

Kulit buah jeruk Mandarin berwarna orange mengandung senyawa karotenoid yang dapat dimanfaatkan sebagai sumber pewarna pangan (Mondello et al., 2005). Karotenoid yaitu kelompok pigmen yang bewarna kuning, orange, merah, yang terlarut dalam lipid, berasal dari tanaman. Karotenoid pada kulit buah jeruk Mandarin selain berpotensi sebagai pewarna makanan juga dapat berpotensi sebagai sumber antioksidan. Antioksidan dapat menunda dan mampu menghambat reaksi oksidasi oleh radikal bebas yang dapat menyebabkan kerusakan sel dan juga merusak biomolekul, seperti DNA, protein, dan lipoprotein di dalam tubuh yang akhirnya dapat memicu terjadinya penyakit degeneratif (Devasagayam et al., 2004).

Ekstrak pewarna dari kulit buah jeruk Mandarin bisa didapatkan melalui proses ekstraksi. Penelitian tentang ekstraksi kulit buah jeruk Mandarin sebagai zat warna sebelumnya sudah dilakukan oleh Saraswati et al. (2018) yaitu mengenai karakteristik pewarna alami dari ekstrak kulit buah jeruk Mandarin (Citrus reticulata) pada perbandingan pelarut etanol dan kloroform dan penelitian oleh Silalahi et al. (2015) tentang karakteristik bubuk ekstrak kulit buah jeruk mandarin (Citrus reticulata) pada perlakuan lama maserasi. Karakteristik zat warna yang diperoleh dari kulit buah jeruk Mandarin yaitu berupa pasta kental, berwarna kuning sampai oranye dan mengandung karotenoid (Saraswati et al., 2018). Zat warna yang kental hasil ekstraksi ini memiliki sifat yang tidak stabil terhadap kondisi lingkungan selama penyimpanan.
Stabilitas dapat didefinisikan sebagai kemampuan suatu bahan untuk dapat bertahan dalam batas yang ditetapkan selama periode masa simpan dan penggunaan agar kualitas dan karakteristiknya masih sama seperti pada saat awal pembuatan (Andriyani et al., 2016). Stabilitas suatu senyawa sangat dipengaruhi oleh kondisi penyimpanan dari bahan yang mengandung senyawa tersebut. Kerusakan ekstrak pewarna pada saat penyimpanan biasanya disebabkan oleh beberapa faktor, dua diantaranya adalah $\mathrm{pH}$ awal dan suhu selama penyimpanan. Perubahan $\mathrm{pH}$ dapat menyebabkan terganggunya sifat elektrostatis dan ikatan hidrogen yang terdapat dalam bahan yang dapat menyebabkan perubahan struktur kromofor (Claire, 1992). Selain $\mathrm{pH}$, suhu juga berpengaruh pada terdegradasinya pigmen. Suhu akan mempercepat reaksi antara zat warna dengan oksigen bebas sehingga proses oksidasi akan semakin cepat berlangsung. Penyimpanan pada $\mathrm{pH}$ awal dan suhu tertentu mempengaruhi kestabilan ekstrak kulit buah jeruk mandarin.

Beberapa penelitian mengenai pengaruh $\mathrm{pH}$ awal dan suhu selama penyimpanan terhadap stabilitas karotenoid telah dilakukan, diantaranya adalah Andriyani et al. (2016) menunjukkan bahwa ekstrak karotenoid dari ekstrak lamun laut (Enhalus acoroides) lebih stabil pada suhu dingin $\left(10 \pm 1^{\circ} \mathrm{C}\right)$ dibandingkan pada suhu ruang $\left(30 \pm 1{ }^{\circ} \mathrm{C}\right)$ selama 8 hari penyimpanan. Penelitian Indriyani et al. (2018) mengenai stabilitas karotenoid ekstrak pewarna buah pandan (Pandanus tectorius) pada suhu dan $\mathrm{pH}$ awal penyimpanan menunjukkan ekstrak pewarna karotenoid buah pandan paling stabil pada $\mathrm{pH}$ 7 (netral) dan penyimpanan suhu dingin 
$\left(4 \pm 3^{\circ} \mathrm{C}\right)$ dibandingkan dengan $\mathrm{pH} 4$ dan $\mathrm{pH}$ 10 pada penyimpanan suhu dingin $\left(4 \pm 3^{\circ} \mathrm{C}\right)$ dan suhu ruang $\left(28 \pm 3^{\circ} \mathrm{C}\right)$ selama penyimpanan 4 minggu.

Hal-hal tersebut di atas menunjukkan bahwa kondisi penyimpanan menentukan stabilitas karotenoid dalam suatu bahan. Sehingga penelitian pengaruh $\mathrm{pH}$ awal dan suhu selama penyimpanan terhadap stabilitas ekstrak pewarna dari kulit buah jeruk Mandarin perlu dilakukan. Tujuan dari penelitian ini adalah mengetahui pengaruh $\mathrm{pH}$ awal dan suhu selama penyimpanan terhadap stabilitas ekstrak pewarna kulit buah jeruk Mandarin serta menentukan $\mathrm{pH}$ awal dan suhu selama penyimpanan terbaik untuk mempertahankan stabilitas ekstrak pewarna kulit buah jeruk Mandarin.

\section{METODE PENELITIAN}

\section{Bahan dan Alat}

Bahan baku yang digunakan dalam penelitian ini yaitu kulit buah jeruk Mandarin berwarna oranye yang diperoleh dari toko buah "Moena Fresh" yang menyediakan produk salad dan jus buah. Bahan kimia yang digunakan kloroform PA (Merck), larutan buffer sitrat $\mathrm{pH} \mathrm{4,} \mathrm{buffer} \mathrm{posfat} \mathrm{pH} 7$, dan buffer posfat $\mathrm{pH} 10$, air distilata, $\mathrm{Na}_{2} \mathrm{SO}_{4}$ anhidrat, asam galat (Sigma-aldrich), kristal DPPH (Himedia) petroleum benzen, aseton, methanol yang semuanya memiliki grade pro analysis.

Peralatan yang digunakan dalam
penelitian ini yaitu: spektrofotometer (Genesys 10S UV-VIS), color reader (Colorimeter PCE-CSM 1, PCE-CSM 2 and PCE-CSM 4), sentrifuse, kertas saring kasar, kertas saring Whatman No. 1, timbangan analitik (Shimadzu ATY224), pipet tetes, tabung reaksi (Iwaki), pipet volume, pipet mikro (Socorex), labu pisah, labu takar, rotary evaporator (Janke \& Kunkel RV 06 ML), vortex (Barntard Thermolyne Maxi Mix II), pinset, spatula, blender (Phillips HR
2115), erlenmeyer (Pyrex), gelas ukur (Herma, Iwaki), gelas beaker (Pyrex), corong pemisah kaca (Pyrex), termometer, $\mathrm{pH}$ meter, oven (Blue M OV-520C-2), desikator (Duran), ayakan 60 mesh, kulkas, alumunium foil, botol kaca, pisau, kain hitam dan tisu.

\section{Rancangan Percobaan}

Percobaan penelitian ini menggunakan rancangan acak lengkap (RAL) faktorial dengan dua faktor. Faktor pertama adalah $\mathrm{pH}$ awal dengan 3 taraf, yaitu: $\mathrm{A} 1=$ $\mathrm{pH} 4, \mathrm{~A} 2=\mathrm{pH} 7, \mathrm{~A} 3=\mathrm{pH} 10$. Faktor kedua adalah suhu dengan 2 taraf, yaitu: $\mathrm{T} 1=4 \pm 3^{\circ} \mathrm{C}$ (suhu dingin), $\mathrm{T} 2=28 \pm 3^{\circ} \mathrm{C}$ (suhu ruang). Masing-masing perlakuan tersebut diulang sebanyak 3 kali sehingga diperoleh 18 unit percobaan. Data yang diperoleh setiap minggu dianalisis dengan analisis variansi, jika perlakuan berpengaruh terhadap variabel yang diamati maka dilanjutkan dengan uji Tukey menggunakan software minitab17 dengan tingkat kepercayaan 95\%. Dibuat grafik penurunan data variabel yang diamati dari kontrol hingga minggu ke-4. Perlakuan terbaik adalah perlakuan yang menghasilkan penurunan kadar karotenoid terkecil.

\section{Pelaksanaan Penelitian}

\section{Pembuatan bubuk kulit buah jeruk Mandarin} (Saraswati et al., 2018)

Pembuatan sampel diawali dengan kulit buah jeruk Mandarin dicuci, kemudian ditiriskan. Selanjutnya dipotong-potong dengan ukuran sekitar $2 \mathrm{~cm} \times 2 \mathrm{~cm}$ untuk mempermudah pengeringan dan penghancuran bahan. Potongan kulit buah jeruk Mandarin dikeringkan ke dalam oven pada suhu $60 \pm$ $5^{\circ} \mathrm{C}$ sampai mudah dihancurkan selama 24 jam. Kemudian kulit buah jeruk Mandarin dihaluskan dengan menggunakan blender. Bubuk kulit buah jeruk Mandarin diayak menggunakan ayakan 60 mesh.

\section{Pembuatan ekstrak kulit buah jeruk Mandarin (Saraswati et al., 2018 dengan modifikasi)}


Pembuatan ekstrak kulit buah jeruk Mandarin dilakukan dengan cara maserasi, yaitu dengan menimbang bubuk kulit buah jeruk sebanyak $70 \mathrm{~g}$ dan kemudian dimasukkan ke dalam labu erlenmeyer, lalu ditambahkan pelarut kloroform sebanyak 700 $\mathrm{ml}$ (perbandingan bahan dengan pelarut ialah 1:10). Selanjutnya, dimaserasi 6 jam pada suhu ruang. Dilakukan pengadukan/penggojogan secara manual setiap 30 menit selama 5 menit, sehingga diperoleh ekstrak bercampur pelarut. Larutan disaring menggunakan kertas saring kasar untuk menyaring ampas yang berukuran besar, sehingga menghasilkan filtrat I dan ampas. Ampas basah yang dihasilkan, ditambahkan pelarut sebanyak $100 \mathrm{ml}$ digojog selama 5 menit, kemudian disaring menggunakan kertas saring kasar sehingga menghasilkan filtrat II. Filtrat I dan filtrat II dicampur, kemudian disaring menggunakan kertas saring Whatman no. 1. Sehingga diperoleh ekstrak yang masih tercampur dengan pelarut. Ekstrak kemudian dimasukkan ke dalam labu rotary vacuum evaporator dievaporasi pada suhu $40^{\circ} \mathrm{C}$ dengan tekanan 100 mBar untuk menghilangkan pelarut yang terdapat dalam ekstrak sehingga didapatkan ekstrak kental. Evaporasi dihentikan pada saat semua pelarut sudah menguap yang ditandai dengan tidak adanya tetesan pelarut.

\section{Uji stabilitas ekstrak kulit buah jeruk Mandarin (Indriyani., et al 2018 dengan modifikasi).}

Proses penyimpanan dilakukan dengan menimbang ekstrak kulit buah jeruk Mandarin sebanyak $1 \mathrm{~g}$ untuk masing-masing perlakuan, kemudian disimpan dalam botol kaca gelap. Sampel ekstrak kulit buah jeruk Mandarin kemudian diatur $\mathrm{pH}$ awalnya dengan cara ditambahkan larutan buffer sesuai perlakuan yaitu $\mathrm{pH} 4,7$, dan 10 hingga seluruh bagian ekstrak larut dalam larutan buffer (10 mL). Kemudian ekstrak disimpan pada suhu sesuai perlakuan yaitu suhu dingin $\left(4 \pm 3^{\circ} \mathrm{C}\right)$ yang disimpan dalam kulkas dan suhu ruang $\left(28 \pm 3^{\circ} \mathrm{C}\right)$ disimpan di dalam ruangan. Dilakukan analisis untuk mengetahui stabilitas ekstrak pewarna kulit buah jeruk Mandarin setiap minggu selama 4 minggu (Lin and Chen, 2005). Pengamatan dilakukan setiap minggu dengan cara mengambil larutan ekstrak dalam larutan buffer sebanyak $0,05 \mathrm{~g}$.

\section{Variabel yang Diamati}

Variabel yang diamati pada ekstrak kulit buah jeruk Mandarin adalah kadar total karotenoid (Muchtadi, 1989), kapasitas antioksidan (Blois, 1958), dan intensitas warna sistem $L^{*}, a^{*}$, dan $b^{*}$ (Weaver, 1996).

\section{HASIL DAN PEMBAHASAN}

\section{Kadar Total Karotenoid}

Hasil analisis ragam total karotenoid menunjukkan bahwa perlakuan $\mathrm{pH}$ awal dan suhu selama penyimpanan berpengaruh sangat nyata $(\mathrm{P}<0,01)$ setiap minggu. Interaksi kedua perlakuan berpengaruh nyata $(\mathrm{P}<0,05)$ pada minggu ke-1 dan berpengaruh sangat nyata $(\mathrm{P}<0,01)$ pada minggu ke-4 tetapi berpengaruh tidak nyata $(\mathrm{P}>0,05)$ pada minggu ke-2 dan 3. Nilai rata-rata total karotenoid selama penyimpanan disajikan dalam Tabel 1.

Tabel 1 menunjukkan bahwa kadar karotenoid pada ekstrak kulit buah jeruk Mandarin pada masing-masing perlakuan mengalami penurunan setiap minggunya. Ekstrak kulit buah jeruk Mandarin (Citrus reticulata) pada minggu ke-0 mempunyai kadar karotenoid sebesar 18,21\%. Pengamatan stabilitas ekstrak pewarna dari kulit buah jeruk Mandarin menunjukkan bahwa semua perlakuan $\mathrm{pH}$ awal dan suhu selama penyimpanan mengakibatkan penurunan pada total karotenoid selama 4 minggu penyimpanan. Penurunan kadar karotenoid untuk masing-masing perlakuan yaitu $\mathrm{pH} 4 ;\left(4 \pm 3^{\circ} \mathrm{C}\right), \mathrm{pH} 4 ;\left(28 \pm 3^{\circ} \mathrm{C}\right), \mathrm{pH} 7 ;\left(4 \pm 3^{\circ} \mathrm{C}\right), \mathrm{pH}$ $7 ;\left(28 \pm 3^{\circ} \mathrm{C}\right), \mathrm{pH} 10 ;\left(4 \pm 3^{\circ} \mathrm{C}\right)$, dan $\mathrm{pH} 10 ;\left(28 \pm 3^{\circ} \mathrm{C}\right)$ dari kontrol hingga minggu keempat berturut- 
turut adalah $63,87 \% ; 67,65 \% ; 42,96 \% ; 52,78 \%$; $49,23 \%$, dan $63,12 \%$. Perlakuan $\mathrm{pH} 7$ dengan penyimpanan suhu dingin $\left(4 \pm 3^{\circ} \mathrm{C}\right)$ merupakan perlakuan yang menghasilkan penurunan kadar karotenoid terkecil yaitu sebesar 42,96\%. Hal ini menunjukkan bahwa karotenoid pada ekstrak pewarna kulit buah jeruk Mandarin paling $65 \%$. stabil pada perlakuan tersebut karena mampu mempertahankan lebih banyak karotenoid selama penyimpanan. Sedangkan pada perlakuan $\mathrm{pH}$ awal 4 (asam) dengan penyimpanan suhu ruang $\left(28 \pm 3^{\circ} \mathrm{C}\right)$ menunjukkan penurunan total karotenoid terbesar yaitu sebesar 67,

Tabel 1. Nilai rata-rata total karotenoid (\%) ekstrak kulit buah jeruk Mandarin pada perlakuan pH awal dan suhu selama penyimpanan pada minggu ke-1 sampai minggu ke-4.

\begin{tabular}{lllll}
\hline & \multicolumn{4}{c}{ Rata-rata kadar karotenoid \pm SD } \\
\cline { 2 - 5 } \multicolumn{1}{c}{ Perlakuan } & Minggu 1 & Minggu 2 & Minggu 3 & Minggu 4 \\
\hline pH 4; $\left(4 \pm 3^{\circ} \mathrm{C}\right)$ & $10,39 \pm 0,37 \mathrm{~d}$ & $7,80 \pm 0,25 \mathrm{a}$ & $7,33 \pm 0,47 \mathrm{a}$ & $6,58 \pm 0,19 \mathrm{c}$ \\
pH 4; $\left(28 \pm 3^{\circ} \mathrm{C}\right)$ & $9,92 \pm 0,17 \mathrm{~d}$ & $7,39 \pm 0,48 \mathrm{a}$ & $6,58 \pm 0,37 \mathrm{a}$ & $5,89 \pm 0,29 \mathrm{c}$ \\
pH 7; $\left(4 \pm 3^{\circ} \mathrm{C}\right)$ & $13,68 \pm 0,55 \mathrm{a}$ & $12,52 \pm 0,40 \mathrm{a}$ & $11,59 \pm 0,51 \mathrm{a}$ & $10,39 \pm 0,41 \mathrm{a}$ \\
pH 7; $\left(28 \pm 3^{\circ} \mathrm{C}\right)$ & $12,07 \pm 0,56 \mathrm{bc}$ & $11,14 \pm 0,52 \mathrm{a}$ & $9,56 \pm 0,44 \mathrm{a}$ & $8,60 \pm 0,53 \mathrm{~b}$ \\
pH 10; $\left(4 \pm 3^{\circ} \mathrm{C}\right)$ & $13,12 \pm 0,75 \mathrm{ab}$ & $10,91 \pm 0,24 \mathrm{a}$ & $9,68 \pm 0,41 \mathrm{a}$ & $9,24 \pm 0,60 \mathrm{~b}$ \\
pH 10; $\left(28 \pm 3^{\circ} \mathrm{C}\right)$ & $10,80 \pm 0,46 \mathrm{~cd}$ & $9,66 \pm 0,60 \mathrm{a}$ & $8,02 \pm 0,32 \mathrm{a}$ & $6,72 \pm 0,17 \mathrm{c}$ \\
\hline
\end{tabular}

Keterangan: Angka yang diikuti huruf yang berbeda pada kolom yang sama menunjukkan berbeda nyata $(\mathrm{P}<0,05)$. Data merupakan rata-rata dari tiga ulangan pada masing-masing perlakuan.

Karotenoid mudah mengalami penurunan pada kondisi asam maupun basa yang disebabkan oleh adanya isomerisasi (Wahyuni dan Widjanarko, 2015). Isomerisasi ini akan mempercepat penurunan intensitas warna karotenoid sehingga kepekatan ekstrak akan berkurang. Pada penyimpanan suhu ruang karotenoid mengalami penurunan pigmen yang tinggi akibat adanya energi panas. Hal ini sesuai dengan pernyataan dari Elbe dan Schwartz (1996), yang menyatakan adanya panas akan menyebabkan terdegradasinya karotenoid yang dapat menyebabkan terjadinya isomerisasi. Isomerisasi ini dapat mengakibatkan perubahan struktur karotenoid dari trans menjadi bentuk cis. Isomerisasi karotenoid dari trans menjadi cis mengakibatkan senyawa karotenoid lebih tidak stabil dan lebih mudah mengalami oksidasi yang dapat mengakibatkan degradasi (Ladislav et al., 2005). Grafik penurunan kadar karotenoid dari kontrol hingga minggu ke-4 disajikan dalam Gambar 1.
Gambar 1 menunjukkan model hubungan antara waktu penyimpanan dengan kadar karotenoid mempunyai nilai koefisien determinasi $\left(\mathrm{R}^{2}\right)$ berkisar antara 0,7592 sampai dengan 0,8672 . Hal ini menunjukkan bahwa waktu penyimpanan berpengaruh terhadap kadar karotenoid pada ekstrak pewarna kulit buah jeruk Mandarin. Nilai koefisien determinasi tertinggi sebesar 0,8672 diperoleh dari perlakuan $\mathrm{pH}$ awal 7 dengan penyimpanan suhu dingin $\left(4 \pm 3^{\circ} \mathrm{C}\right)$, yang artinya $86,72 \%$ kadar karotenoid dipengaruhi oleh waktu penyimpanan dan $13,28 \%$ dipengaruhi faktor lain diantaranya zat kimia, oksigen, dan cahaya.

Persamaan pada masing-masing perlakuan menunjukkan adanya penurunan kadar karotenoid pada ekstrak pewarna dari kulit buah jeruk Mandarin. Perlakuan yang mengalami laju penurunan totalkarotenoid terkecil yaitu perlakuan $\mathrm{pH}$ awal 7 (netral) dengan penyimpanan suhu dingin $\left(4 \pm 3^{\circ} \mathrm{C}\right)$ yaitu sebesar 1,773. Hal tersebut menunjukkan bahwa kadar karotenoid pada ekstrak pewarna kulit buah jeruk Mandarin 
paling stabil pada perlakuan tersebut dibandingkan perlakuan lainnya. Pada perlakuan $\mathrm{pH}$ awal 7 dengan penyimpanan suhu dingin $\left(4 \pm 3^{\circ} \mathrm{C}\right)$, kadar karotenoid mengalami kerusakan paling sedikit yang ditunjukkan oleh laju penurunan kadar karotenoid dengan nilai terkecil setiap minggunya. Kadar karotenoid mengalami degradasi paling rendah pada suhu dingin dibandingkan dengan suhu ruang. Pada suhu yang lebih tinggi menyebabkan adanya energi panas sehingga karotenoid mudah mengalami degradasi akibat terjadi reaksi pemutusan pada ikatan rangkap terkojugasi pada molekul karotenoid (Lubis et al., 2012). Hal ini sesuai dengan penelitian Indriyani et al. (2018), yaitu pigmen karotenoid buah pandan memiliki tingkat kestabilan yang lebih tinggi pada $\mathrm{pH}$ netral dengan kondisi penyimpanan menggunakan suhu dingin. Stabilitas pigmen karotenoid berkaitan dengan adanya ikatan rangkap terkonjugasi pada struktur karotenoid dan dapat mengalami kerusakan akibat oksidasi oleh zat kimia, enzim, suhu, oksigen, dan cahaya (Belitz et al., 2009).

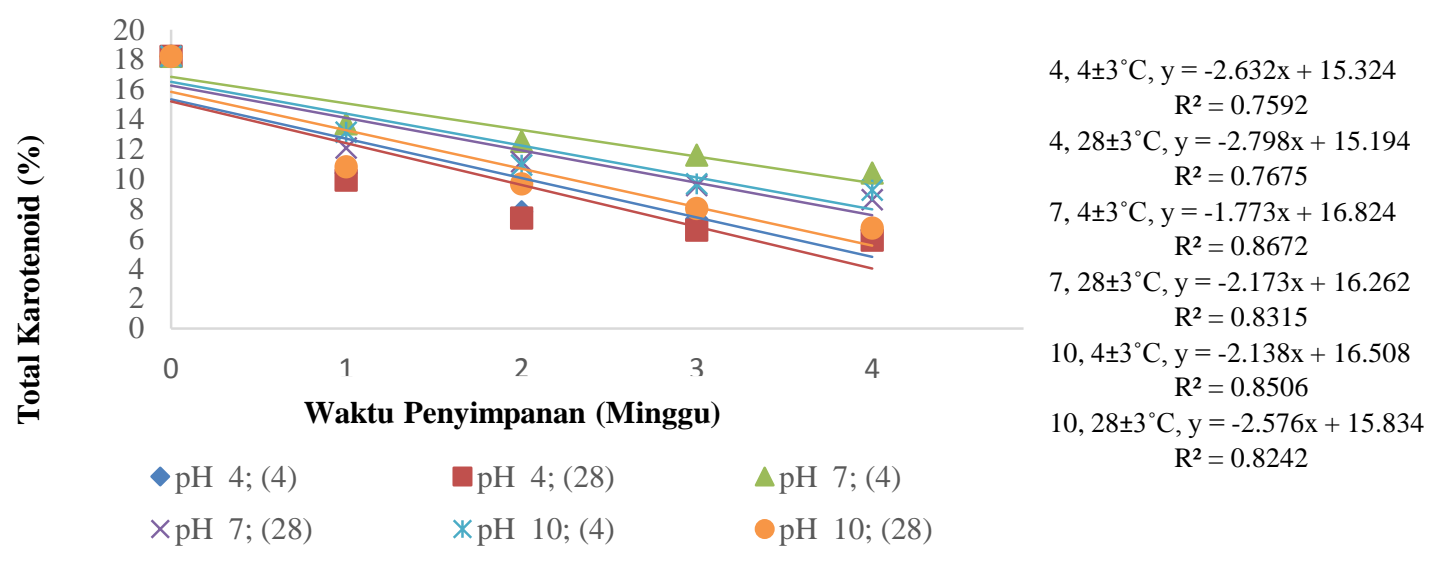

Gambar 1. Grafik penurunan total karotenoid ekstrak kulit buah jeruk Mandarin pada perlakuan $\mathrm{pH}$ awal dan suhu selama penyimpanan.

\section{Kapasitas Antioksidan}

Hasil analisis ragam kapasitas antioksidan ekstrak pewarna kulit buah jeruk Mandarin menunjukkan bahwa perlakuan $\mathrm{pH}$ awal, suhu selama penyimpanan dan interaksi kedua perlakuan berpengaruh sangat nyata $(\mathrm{P}<0,01)$ pada setiap minggu. Nilai rata-rata kapasitas antioksidan ekstrak kulit buah jeruk Mandarin selama penyimpanan dapat dilihat pada Tabel 2.

Tabel 2. Nilai rata-rata kapasitas antioksidan (\%) ekstrak kulit buah jeruk Mandarin pada perlakuan $\mathrm{pH}$ awal dan suhu selama penyimpanan pada minggu ke-1 sampai minggu ke-4.

\begin{tabular}{lllll}
\hline & \multicolumn{4}{c}{ Rata-rata kapasitas antioksidan \pm SD } \\
\cline { 2 - 5 } \multicolumn{1}{c}{ Perlakuan } & Minggu 1 & Minggu 2 & Minggu 3 & Minggu 4 \\
\hline pH 4; $\left(4 \pm 3^{\circ} \mathrm{C}\right)$ & $72,76 \pm 0,87 \mathrm{~cd}$ & $68,29 \pm 0,87 \mathrm{c}$ & $65,38 \pm 0,73 \mathrm{c}$ & $58,68 \pm 0,36 \mathrm{de}$ \\
pH 4; $\left(28 \pm 3^{\circ} \mathrm{C}\right)$ & $71,46 \pm 0,58 \mathrm{~d}$ & $65,89 \pm 0,71 \mathrm{~d}$ & $61,13 \pm 0,79 \mathrm{~d}$ & $56,81 \pm 1,0 \mathrm{e}$ \\
pH 7; $\left(4 \pm 3^{\circ} \mathrm{C}\right)$ & $82,12 \pm 0,94 \mathrm{a}$ & $77,85 \pm 0,79 \mathrm{a}$ & $72,23 \pm 0,58 \mathrm{a}$ & $68,43 \pm 0,73 \mathrm{a}$ \\
pH 7; $\left(28 \pm 3^{\circ} \mathrm{C}\right)$ & $77,9 \pm 0,66 \mathrm{~b}$ & $72,56 \pm 0,94 \mathrm{~b}$ & $68,87 \pm 0,74 \mathrm{~b}$ & $62,67 \pm 0,44 \mathrm{c}$ \\
pH 10; $\left(4 \pm 3^{\circ} \mathrm{C}\right)$ & $80,06 \pm 0,66 \mathrm{ab}$ & $76,5 \pm 0,65 \mathrm{a}$ & $70,55 \pm 0,52 \mathrm{ab}$ & $65,46 \pm 0,94 \mathrm{~b}$ \\
pH 10; $\left(28 \pm 3^{\circ} \mathrm{C}\right)$ & $74,77 \pm 1,10 \mathrm{c}$ & $69,39 \pm 0,80 \mathrm{c}$ & $64,21 \pm 0,58 \mathrm{c}$ & $59,60 \pm 0,86 \mathrm{~d}$ \\
\hline
\end{tabular}

Keterangan: Angka yang diikuti huruf yang berbeda pada kolom yang sama menunjukkan berbeda nyata $(\mathrm{P}<0,05)$. Data merupakan rata-rata dari tiga ulangan pada masing-masing perlakuan. 
Tabel 2 menunjukkan bahwa kapasitas antioksidan pada ekstrak kulit buah jeruk Mandarin pada masing-masing perlakuan mengalami penurunan setiap minggunya.

Kapasitas antioksidan pada ekstrak kulit buah jeruk Mandarin pada minggu ke-0 yaitu sebesar $86,64 \%$. Pengamatan kapasitas antioksidan ekstrak kulit buah jeruk Mandarin menunjukkan bahwa semua perlakuan $\mathrm{pH}$ awal dan suhu selama penyimpanan pada ekstrak pewarna dari kulit buah jeruk Mandarin mengakibatkan penurunan pada kapasitas antioksidan selama 4 minggu penyimpanan..

Penurunan kapasitas antioksidan untuk masing-masing perlakuan yaitu $\mathrm{pH} 4 ;\left(4 \pm 3^{\circ} \mathrm{C}\right)$, $\mathrm{pH} 4 ;\left(28 \pm 3^{\circ} \mathrm{C}\right), \mathrm{pH} 7 ;\left(4 \pm 3^{\circ} \mathrm{C}\right), \mathrm{pH} 7 ;\left(28 \pm 3^{\circ} \mathrm{C}\right)$, $\mathrm{pH} 10 ;\left(4 \pm 3^{\circ} \mathrm{C}\right)$, dan $\mathrm{pH} 10 ;\left(28 \pm 3^{\circ} \mathrm{C}\right)$ dari kontrol hingga minggu keempat berturut-turut adalah $32,27 \% ; 34,43 \% ; 21,02 \% ; 27,67 \% ; 24,45 \%$; dan
$31,21 \%$. Perlakuan $\mathrm{pH} 7$ dan penyimpanan suhu dingin $\left(4 \pm 3^{\circ} \mathrm{C}\right)$ merupakan perlakuan yang menunjukkan penurunan kapasitas antioksidan terkecil yaitu sebesar 21,02\%. Hal ini menunjukkan bahwa kapasitas antioksidan pada ekstrak pewarna kulit buah jeruk Mandarin paling stabil pada perlakuan tersebut dibandingkan perlakuan lainnya selama penyimpanan. Hal ini disebabkan ekstrak kulit buah jeruk Mandarin pada $\mathrm{pH}$ awal 7 dan penyimpanan suhu dingin $\left(4 \pm 3^{\circ} \mathrm{C}\right)$ mempunyai kadar karotenoid paling tinggi dibandingkan dengan perlakuan lainnya, yang telah dikonfirmasi dari hasil analisa kadar karotenoid pada Tabel 1. Senyawa karotenoid bersifat antioksidan, sehingga makin tinggi kadar karotenoid, maka kapasitas antioksidan juga semakin tinggi. Grafik penurunan kapasitas antioksidan dari kontrol hingga minggu ke-4 disajikan dalam Gambar 2

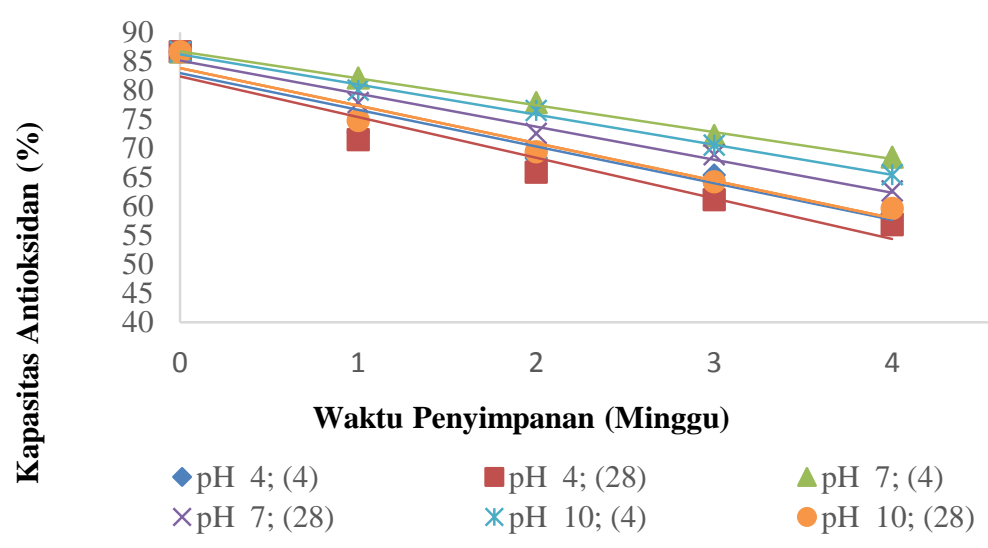

$$
\begin{array}{r}
4,4 \pm 3^{\circ} \mathrm{C}, \mathrm{y}=-6.33 \mathrm{x}+83.01 \\
\mathrm{R}^{2}=0.9184 \\
4,28 \pm 3^{\circ} \mathrm{C}, \mathrm{y}=-6.999 \mathrm{x}+82.384 \\
\mathrm{R}^{2}=0.9147 \\
7,4 \pm 3^{\circ} \mathrm{C}, \mathrm{y}=-4.631 \mathrm{x}+86.716 \\
\mathrm{R}^{2}=0.9973 \\
7,28 \pm 3^{\circ} \mathrm{C}, \mathrm{y}=-5.697 \mathrm{x}+85.122 \\
\mathrm{R}^{2}=0.9794 \\
10,4 \pm 3^{\circ} \mathrm{C}, \mathrm{y}=-5.187 \mathrm{x}+86.216 \\
\mathrm{R}^{2}=0.9942 \\
10,28 \pm 3^{\circ} \mathrm{C}, \mathrm{y}=-6.464 \mathrm{x}+83.85 \\
\mathrm{R}^{2}=0.9552
\end{array}
$$

$$
\begin{array}{lll}
\diamond \mathrm{pH} \mathrm{4}(4) & \square \mathrm{pH} 4 ;(28) & \triangle \mathrm{pH} 7 ;(4) \\
\times \mathrm{pH} 7 ;(28) & \times \mathrm{pH} 10 ;(4) & \mathrm{pH} 10 ;(28)
\end{array}
$$

Gambar 2. Grafik penurunan kapasitas antioksidan ekstrak kulit buah jeruk Mandarin pada perlakuan $\mathrm{pH}$ awal awal dan suhu selama penyimpanan.

Gambar 2 menunjukkan model hubungan antara waktu penyimpanan dengan kapasitas antioksidan mempunyai nilai koefisien determinasi $\left(\mathrm{R}^{2}\right)$ berkisar antara 0,9147 sampai dengan 0,9973. Hal ini menunjukkan bahwa waktu penyimpanan berpengaruh terhadap kapasitas antioksidan pada ekstrak pewarna kulit buah jeruk Mandarin. Nilai koefisien determinasi tertinggi sebesar 0,9973 diperoleh dari perlakuan $\mathrm{pH}$ awal 7 dan suhu dingin $\left(4 \pm 3^{\circ} \mathrm{C}\right)$ yang artinya $99,73 \%$ kapasitas antioksidan dipengaruhi oleh waktu penyimpanan, dan $0,27 \%$ dipengaruhi faktor lain diantaranya zat kimia, oksigen, dan cahaya.

Persamaan pada masing-masing perlakuan menunjukkan adanya penurunan kapasitas antoksidan pada ekstrak pewarna 
dari kulit buah jeruk Mandarin. Perlakuan yang mengalami laju penurunan kapasitas antioksidan terkecil yaitu perlakuan $\mathrm{pH}$ awal 7 (netral) dengan penyimpanan suhu dingin pada perlakuan $\mathrm{pH}$ awal 7 dengan penyimpanan suhu dingin $\left(4 \pm 3^{\circ} \mathrm{C}\right)$ dibandingkan dengan perlakuan lainnya. Pada perlakuan $\mathrm{pH}$ awal 7 dan suhu dingin $\left(4 \pm 3^{\circ} \mathrm{C}\right)$ mengalami laju penurunan kapasitas antioksidan paling kecil, hasil ini sesuai dengan laju penurunan kadar karotenoid paling kecil pada perlakuan $\mathrm{pH}$ awal 7 dan suhu dingin $\left(4 \pm 3^{\circ} \mathrm{C}\right)$ selama penyimpanan. Pigmen karotenoid memiliki tingkat kestabilan yang lebih tinggi pada $\mathrm{pH}$ netral (Oktafia et al., 2015). Selain itu karotenoid juga lebih stabil pada kondisi suhu rendah selama penyimpanan (Wulansari, 2020). $\left(4 \pm 3^{\circ} \mathrm{C}\right)$ yaitu sebesar 4,631. Hal ini menunjukkan antioksidan yang terdapat pada ekstrak pewarna kulit buah jeruk Mandarin lebih stabil

Hasil analisis ragam pada nilai tingkat kecerahan menunjukkan bahwa perlakuan $\mathrm{pH}$ awal berpengaruh sangat nyata pada setiap minggunya $(\mathrm{P}<0,01)$. Perlakuan suhu selama penyimpanan berpengaruh tidak nyata pada minggu ke-1 dan minggu ke-3 $(\mathrm{P}>0,05)$ tetapi berpengaruh sangat nyata pada minggu ke-2 dan minggu ke-4 $(\mathrm{P}<0,01)$. Interaksi kedua perlakuan menunjukkan berpengaruh sangat nyata $(\mathrm{P}<0,01)$ untuk minggu ke- 1,2 , dan 3 dan berpengaruh nyata pada minggu ke-4 $(\mathrm{P}<0,05)$. Nilai rata-rata tingkat kecerahan (L*) selama penyimpanan disajikan dalam Tabel 3.

\section{Tingkat Kecerahan $\left(\mathrm{L}^{*}\right)$}

Tabel 3. Nilai rata-rata tingkat kecerahan ( $\left.\mathrm{L}^{*}\right)$ ekstrak kulit buah jeruk Mandarin pada perlakuan $\mathrm{pH}$ awal dan suhu selama penyimpanan pada minggu ke-1 sampai minggu ke-4.

\begin{tabular}{lllll}
\hline & \multicolumn{4}{c}{ Rata-rata nilai tingkat kecerahan $\left(\mathrm{L}^{*}\right) \pm \mathrm{SD}$} \\
\cline { 2 - 5 } \multicolumn{1}{c}{ Perlakuan } & Minggu 1 & Minggu 2 & Minggu 3 & Minggu 4 \\
\hline $\mathrm{pH} \mathrm{4;}\left(4 \pm 3^{\circ} \mathrm{C}\right)$ & $29,42 \pm 0,92 \mathrm{c}$ & $34,4 \pm 0,54 \mathrm{~b}$ & $36,78 \pm 0,44 \mathrm{~b}$ & $37,84 \pm 0,29 \mathrm{c}$ \\
$\mathrm{pH} 4 ;\left(28 \pm 3^{\circ} \mathrm{C}\right)$ & $30,03 \pm 0,34 \mathrm{c}$ & $31,15 \pm 2,58 \mathrm{~cd}$ & $35,01 \pm 1,35 \mathrm{~b}$ & $40,27 \pm 0,53 \mathrm{~b}$ \\
$\mathrm{pH} \mathrm{7} ;\left(4 \pm 3^{\circ} \mathrm{C}\right)$ & $26,91 \pm 0,19 \mathrm{~d}$ & $27,85 \pm 0,48 \mathrm{e}$ & $29,09 \pm 1,35 \mathrm{c}$ & $31,07 \pm 0,45 \mathrm{~d}$ \\
$\mathrm{pH} \mathrm{7}\left(28 \pm 3^{\circ} \mathrm{C}\right)$ & $28,49 \pm 1,15 \mathrm{~cd}$ & $29,77 \pm 0,35 \mathrm{de}$ & $31,12 \pm 0,40 \mathrm{c}$ & $32,06 \pm 0,13 \mathrm{~d}$ \\
$\mathrm{pH} \mathrm{10}\left(4 \pm 3^{\circ} \mathrm{C}\right)$ & $35,98 \pm 0,37 \mathrm{a}$ & $38,12 \pm 0,25 \mathrm{a}$ & $39,23 \pm 0,43 \mathrm{a}$ & $39,58 \pm 0,70 \mathrm{~b}$ \\
$\mathrm{pH} \mathrm{10} ;\left(28 \pm 3^{\circ} \mathrm{C}\right)$ & $32,91 \pm 0,49 \mathrm{~b}$ & $33,04 \pm 0,46 \mathrm{bc}$ & $37,02 \pm 0,41 \mathrm{ab}$ & $42,44 \pm 0,94 \mathrm{a}$ \\
\hline
\end{tabular}

Keterangan: Angka yang diikuti huruf yang berbeda pada kolom yang sama menunjukkan berbeda nyata $(\mathrm{P}<0,05)$. Data merupakan rata-rata dari tiga ulangan pada masing-masing perlakuan.

Tabel 3 menunjukkan bahwa nilai tingkat kecerahan $\left(\mathrm{L}^{*}\right)$ pada ekstrak kulit buah jeruk Mandarin pada masing-masing perlakuan mengalami kenaikan setiap minggunya. Tingkat kecerahan $\left(\mathrm{L}^{*}\right)$ minggu ke-0 pada ekstrak kulit buah jeruk Mandarin yang diperoleh adalah sebesar 22,88. Semakin besar nilai ( $\left.\mathrm{L}^{*}\right)$ produk semakin cerah. Pengamatan nilai tingkat kecerahan $\left(L^{*}\right)$ ekstrak pewarna dari kulit buah jeruk Mandarin menunjukkan bahwa semua perlakuan $\mathrm{pH}$ awal dan suhu selama penyimpanan mengakibatkan kenaikan pada nilai tingkat kecerahan $\left(\mathrm{L}^{*}\right)$ selama 4 minggu penyimpanan.
Kenaikan nilai tingkat kecerahan $\left(\mathrm{L}^{*}\right)$ untuk masing-masing perlakuan yaitu $\mathrm{pH}$ $4 ;\left(4 \pm 3^{\circ} \mathrm{C}\right), \mathrm{pH} 4 ;\left(28 \pm 3^{\circ} \mathrm{C}\right), \mathrm{pH} 7 ;\left(4 \pm 3^{\circ} \mathrm{C}\right), \mathrm{pH}$ $7 ;\left(28 \pm 3^{\circ} \mathrm{C}\right), \mathrm{pH} 10 ;\left(4 \pm 3^{\circ} \mathrm{C}\right)$, dan $\mathrm{pH} 10 ;\left(28 \pm 3^{\circ} \mathrm{C}\right)$ dari kontrol hingga minggu keempat berturutturut adalah $39,53 \% ; 43,18 \% ; 26,36 \% ; 28,63 \%$; 42,19\%; dan 46,09\%. Perlakuan pH 7 dengan penyimpanan suhu dingin $\left(4 \pm 3^{\circ} \mathrm{C}\right)$ merupakan perlakuan yang mengakibatkan kenaikan nilai tingkat kecerahan $\left(\mathrm{L}^{*}\right)$ terkecil yaitu sebesar $26,36 \%$. Hal ini menunjukkan bahwa nilai tingkat kecerahan pada ekstrak pewarna kulit buah jeruk Mandarin paling stabil pada perlakuan tersebut dibandingkan perlakuan lainnya selama 
penyimpanan. Menurut Wahyuni dan Widjanarko (2015), kandungan pigmen dalam suatu bahan akan mempengaruhi nilai kecerahannya. Kandungan pigmen karotenoid ekstrak kulit buah jeruk Mandarin yang paling tinggi yaitu pada perlakuan $\mathrm{pH} 7$ dan penyimpanan suhu dingin $\left(4 \pm 3^{\circ} \mathrm{C}\right)$.
Semakin tinggi pigmen karotenoid dalam ekstrak maka nilai kecerahan akan semakin rendah (gelap) begitu juga sebaliknya. Grafik kenaikan nilai tingkat kecerahan $\left(\mathrm{L}^{*}\right)$ dari kontrol hingga minggu ke-4 disajikan dalam Gambar 3.

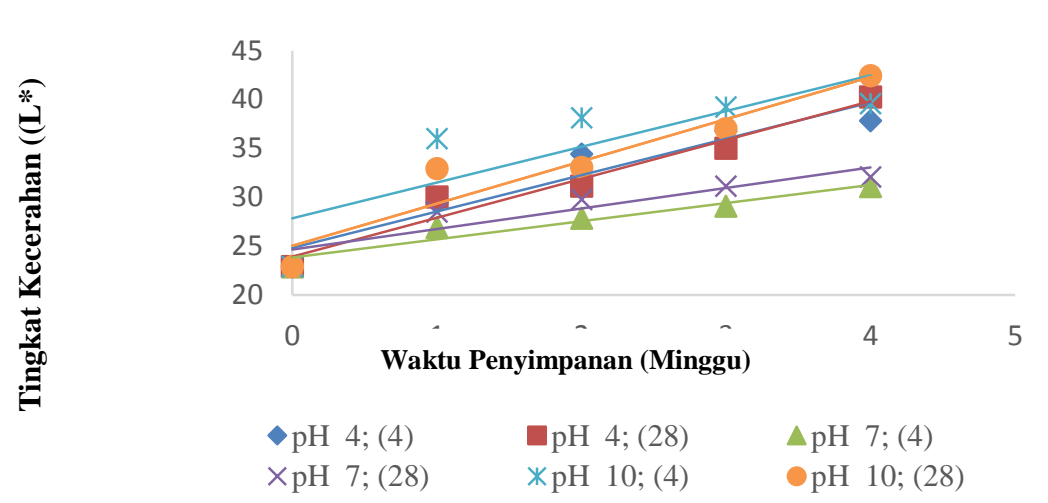

$$
\begin{aligned}
4,4 \pm 3^{\circ} \mathrm{C}, \mathrm{y} & =3.728 \mathrm{x}+24.808 \\
\mathrm{R}^{2} & =0.9132 \\
4,28 \pm 3^{\circ} \mathrm{C}, \mathrm{y} & =3.976 \mathrm{x}+23.916 \\
\mathrm{R}^{2} & =0.9573 \\
7,4 \pm 3^{\circ} \mathrm{C}, \mathrm{y} & =1.856 \mathrm{x}+23.848 \\
\mathrm{R}^{2} & =0.9293 \\
7,28 \pm 3^{\circ} \mathrm{C}, \mathrm{y} & =2.099 \mathrm{x}+24.666 \\
\mathrm{R}^{2} & =0.8461 \\
10,4 \pm 3^{\circ} \mathrm{C}, \mathrm{y} & =3.665 \mathrm{x}+27.828 \\
\mathrm{R}^{2} & =0.6842 \\
10,28 \pm 3^{\circ} \mathrm{C}, \mathrm{y} & =4.323 \mathrm{x}+25.012 \\
\mathrm{R}^{2} & =0.9093
\end{aligned}
$$

$\begin{array}{lll}\diamond \mathrm{pH} 4 ;(4) & \square \mathrm{pH} 4 ;(28) & \triangle \mathrm{pH} 7 ;(4) \\ \times \mathrm{pH} 7 ;(28) & * \mathrm{pH} 10 ;(4) & \mathrm{pH} 10 ;(28)\end{array}$

Gambar 3. Grafik kenaikan nilai kecerahan $\left(\mathrm{L}^{*}\right)$ ekstrak kulit buah jeruk Mandarin pada perlakuan $\mathrm{pH}$ awal dan suhu selama penyimpanan.

Gambar 3 menunjukkan model hubungan antara waktu penyimpanan dengan nilai tingkat kecerahan $\left(\mathrm{L}^{*}\right)$ mempunyai nilai koefisien determinasi $\left(\mathrm{R}^{2}\right)$ berkisar antara 0,6842 sampai dengan 0,9573. Hal ini menunjukkan bahwa waktu penyimpanan berpengaruh terhadap nilai tingkat kecerahan (L*) pada ekstrak pewarna kulit buah jeruk Mandarin. Nilai koefisien determinasi tertinggi sebesar 0,9573 diperoleh dari perlakuan $\mathrm{pH}$ awal 4 dengan penyimpanan suhu ruang $\left(28 \pm 3^{\circ} \mathrm{C}\right)$, yang artinya $95,73 \%$ nilai tingkat kecerahan $\left(\mathrm{L}^{*}\right)$ dipengaruhi oleh waktu penyimpanan dan $4,27 \%$ dipengaruhi faktor lain diantaranya zat kimia, oksigen, dan cahaya.

Laju kenaikan nilai tingkat kecerahan terkecil terdapat pada perlakuan $\mathrm{pH}$ awal 7 dan penyimpanan suhu dingin $\left(4 \pm 3^{\circ} \mathrm{C}\right)$ yaitu sebesar 1,856. Hal ini menunjukkan bahwa kenaikan nilai tingkat kecerahan $\left(\mathrm{L}^{*}\right)$ terkecil didapatkan pada perlakuan $\mathrm{pH}$ awal 7 dengan penyimpanan suhu dingin $\left(4 \pm 3^{\circ} \mathrm{C}\right)$, hasil ini membuktikan bahwa penyimpanan dengan perlakuan tersebut paling stabil dibandingkan perlakuan lainnya Warna ekstrak kulit buah jeruk Mandarin yang semakin terang karena terjadinya kerusakan struktur trans beta karoten. Menurut Manasika dan Widjanarko (2015), semakin banyak pigmen menyebabkan ekstrak akan semakin gelap dan pekat sehingga nilai kecerahan menurun. Karotenoid akan mudah mengalami isomerisasi pada $\mathrm{pH}$ asam maupun basa yang akan mempercepat oksidasi dan penurunan intensitas pigmen warna karotenoid sehingga kepekatan ekstrak akan berkurang dan meningkatkan nilai kecerahan (Wahyuni dan Widjanarko, 2015).

\section{Tingkat Kemerahan (a*)}

Hasil analisis ragam pada nilai kemerahan $\left(\mathrm{a}^{*}\right)$ menunjukkan bahwa perlakuan $\mathrm{pH}$ awal dan suhu selama penyimpanan berpengaruh sangat nyata pada setiap minggu $(\mathrm{P}<0,01)$. Interaksi kedua perlakuan berpengaruh nyata pada minggu ke-1 $(\mathrm{P}<0,05)$ tetapi berpengaruh tidak nyata pada minggu ke-2, 3, dan $4(\mathrm{P}>0,05)$. Nilai rata-rata tingkat kemerahan $\left(\mathrm{a}^{*}\right)$ selama penyimpanan disajikan dalam Tabel 4 . 
Tabel 4. Nilai rata-rata tingkat kemerahan $\left(\mathrm{a}^{*}\right)$ ekstrak kulit buah jeruk Mandarin pada perlakuan $\mathrm{pH}$ awal dan suhu selama penyimpanan pada minggu ke-1 sampai minggu ke-4.

\begin{tabular}{lllll}
\hline & \multicolumn{4}{c}{ Rata-rata nilai tingkat kemerahan (a*) \pm SD } \\
\cline { 2 - 5 } \multicolumn{1}{c}{ Perlakuan } & Minggu 1 & Minggu 2 & Minggu 3 & Minggu 4 \\
\hline pH 4; $\left(4 \pm 3^{\circ} \mathrm{C}\right)$ & $18,15 \pm 0,38 \mathrm{~b}$ & $16,00 \pm 0,35 \mathrm{a}$ & $13,86 \pm 0,38 \mathrm{a}$ & $12,47 \pm 0,28 \mathrm{a}$ \\
$\mathrm{pH} \mathrm{4;}\left(28 \pm 3^{\circ} \mathrm{C}\right)$ & $13,75 \pm 1,02 \mathrm{~d}$ & $12,96 \pm 1,29 \mathrm{a}$ & $11,78 \pm 0,86 \mathrm{a}$ & $10,76 \pm 0,36 \mathrm{a}$ \\
$\mathrm{pH} \mathrm{7;}\left(4 \pm 3^{\circ} \mathrm{C}\right)$ & $22,06 \pm 0,46 \mathrm{a}$ & $21,51 \pm 0,77 \mathrm{a}$ & $21,16 \pm 0,65 \mathrm{a}$ & $20,86 \pm 0,57 \mathrm{a}$ \\
$\mathrm{pH} \mathrm{7;}\left(28 \pm 3^{\circ} \mathrm{C}\right)$ & $21,18 \pm 0,39 \mathrm{a}$ & $20,87 \pm 0,47 \mathrm{a}$ & $20,21 \pm 0,38 \mathrm{a}$ & $20,09 \pm 0,31 \mathrm{a}$ \\
pH 10; $\left(4 \pm 3^{\circ} \mathrm{C}\right)$ & $16,7 \pm 1,15 \mathrm{bc}$ & $15,60 \pm 1,11 \mathrm{a}$ & $13,47 \pm 0,73 \mathrm{a}$ & $12,24 \pm 0,36 \mathrm{a}$ \\
$\mathrm{pH} \mathrm{10;}\left(28 \pm 3^{\circ} \mathrm{C}\right)$ & $14,31 \pm 1,52 \mathrm{~cd}$ & $13,95 \pm 1,36 \mathrm{a}$ & $12,26 \pm 1,00 \mathrm{a}$ & $11,03 \pm 0,37 \mathrm{a}$ \\
\hline
\end{tabular}

Keterangan: Angka yang diikuti huruf yang berbeda pada kolom yang sama menunjukkan berbeda nyata $(\mathrm{P}<0,05)$. Data merupakan rata-rata dari tiga ulangan pada masing-masing perlakuan.

Tabel 4 menunjukkan bahwa nilai tingkat kemerahan $\left(a^{*}\right)$ pada ekstrak kulit buah jeruk Mandarin pada masing-masing perlakuan mengalami penurunan setiap minggunya. Nilai tingkat kemerahan $\left(\mathrm{a}^{*}\right)$ minggu ke-0 pada ekstrak pewarna dari kulit buah jeruk Mandarin diperoleh sebesar 26,37. Pengamatan nilai tingkat kemerahan $\left(\mathrm{a}^{*}\right)$ ekstrak kulit buah jeruk Mandarin menunjukkan bahwa semua perlakuan $\mathrm{pH}$ awal dan suhu selama penyimpanan mengakibatkan penurunan pada nilai tingkat kemerahan $\left(\mathrm{a}^{*}\right)$ selama 4 minggu penyimpanan. Penurunan nilai tingkat kemerahan $\left(\mathrm{a}^{*}\right)$ untuk masing-masing perlakuan yaitu $\mathrm{pH} \quad 4 ;\left(4 \pm 3^{\circ} \mathrm{C}\right), \mathrm{pH} \quad 4 ;\left(28 \pm 3^{\circ} \mathrm{C}\right), \quad \mathrm{pH}$ $7 ;\left(4 \pm 3^{\circ} \mathrm{C}\right), \mathrm{pH} 7 ;\left(28 \pm 3^{\circ} \mathrm{C}\right), \mathrm{pH} 10 ;\left(4 \pm 3^{\circ} \mathrm{C}\right)$, dan $\mathrm{pH} 10 ;\left(28 \pm 3^{\circ} \mathrm{C}\right)$ dari kontrol hingga minggu keempat berturut-turut adalah $52,71 \% ; 59,20 \%$; $20,89 \%$; 23,81\%; 53,58\%; dan 58,17\%. Perlakuan $\mathrm{pH} 7$ dengan penyimpanan suhu dingin $\left(4 \pm 3^{\circ} \mathrm{C}\right)$ menunjukkan penurunan nilai tingkat kemerahan paling kecil yaitu 20,89\%. Penurunan nilai kemerahan ini diakibatkan oleh pigmen karotenoid yang memberikan nilai kemerahan telah mengalami degradasi atau kerusakan. Grafik penurunan nilai tingkat kemerahan $\left(a^{*}\right)$ dari kontrol hingga minggu ke-4 disajikan dalam Gambar 4.

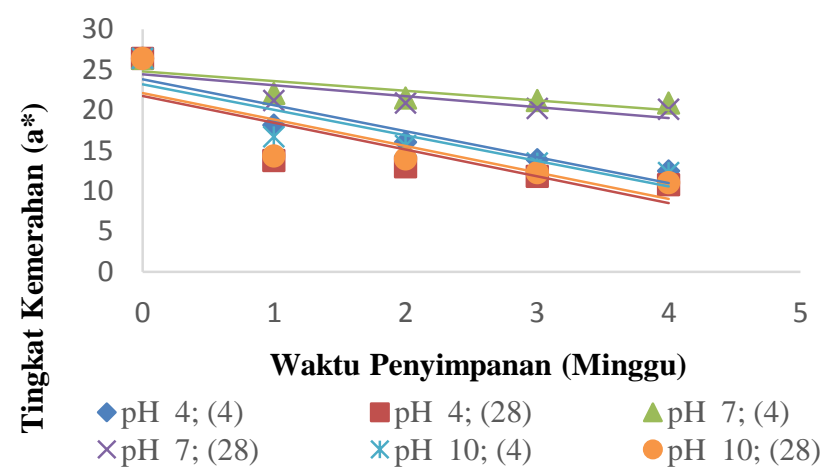

$$
\begin{aligned}
4,4 \pm 3^{\circ} \mathrm{C}, \mathrm{y} & =-3.209 \mathrm{x}+23.788 \\
\mathrm{R}^{2} & =0.8595 \\
4,28 \pm 3^{\circ} \mathrm{C}, \mathrm{y} & =-3.319 \mathrm{x}+21.762 \\
\mathrm{R}^{2} & =0.6747 \\
7,4 \pm 3^{\circ} \mathrm{C}, \mathrm{y} & =-1.192 \mathrm{x}+24.776 \\
\mathrm{R}^{2} & =0.6905 \\
7,28 \pm 3^{\circ} \mathrm{C}, \mathrm{y} & =-1.353 \mathrm{x}+24.45 \\
\mathrm{R}^{2} & =0.664 \\
10,4 \pm 3^{\circ} \mathrm{C}, \mathrm{y} & =-3.149 \mathrm{x}+23.174 \\
\mathrm{R}^{2} & =0.794 \\
10,28 \pm 3^{\circ} \mathrm{C}, \mathrm{y} & =-3.273 \mathrm{x}+22.13 \\
\mathrm{R}^{2} & =0.7028
\end{aligned}
$$

Gambar 4. Grafik penurunan nilai kemerahan ( $\left.\mathrm{a}^{*}\right)$ ekstrak kulit buah jeruk Mandarin pada perlakuan $\mathrm{pH}$ awal dan suhu selama penyimpanan.

Gambar 4 menunjukkan model hubungan antara waktu penyimpanan dengan nilai tingkat kemerahan $\left(a^{*}\right)$ mempunyai nilai koefisien determinasi $\left(\mathrm{R}^{2}\right)$ berkisar antara

Nilai koefisien determinasi tertinggi sebesar 0,8595 diperoleh dari perlakuan $\mathrm{pH}$
0,664 sampai dengan 0,8595 . Hal ini menunjukkan bahwa waktu penyimpanan berpengaruh terhadap warna kemerahan $\left(a^{*}\right)$ pada ekstrak kulit buah jeruk Mandarin awal 4 dengan penyimpanan suhu dingin $\left(4 \pm 3^{\circ} \mathrm{C}\right)$, yang artinya $85,95 \%$ nilai tingkat 
kemerahan (a*) dipengaruhi oleh waktu penyimpanan dan $14,05 \%$ dipengaruhi faktor lain diantaranya zat kimia, oksigen, dan cahaya.

Tingkat kemerahan berkaitan dengan kadar karotenoid dalam ekstrak. Makin tinggi kadar karotenoid maka nilai rinhgkat kemerahan semakin tinggi. Laju penurunan nilai tingkat kemerahan $\left(\mathrm{a}^{*}\right)$ terkecil terdapat pada perlakuan $\mathrm{pH}$ awal 7 dengan penyimpanan suhu dingin $\left(4 \pm 3^{\circ} \mathrm{C}\right)$ yaitu sebesar 1,192. Hal ini menunjukkan bahwa pigmen karotenoid yang terdapat dalam ekstrak pewarna dari kulit buah jeruk Mandarin stabil pada perlakuan tersebut karena paling kecil mengalami penurunan nilai tingkat kemerahan dibandingkan dengan perlakuan lainnya. Hasil ini sesuai dengan laju penurunan kadar karotenoid paling kecil pada perlakuan $\mathrm{pH}$ awal 7 dengan penyimpanan suhu dingin $\left(4 \pm 3^{\circ} \mathrm{C}\right)$. Kandungan pigmen karotenoid ekstrak kulit buah jeruk Mandarin yang paling tinggi yaitu pada perlakuan $\mathrm{pH}$ awal 7 dengan penyimpanan suhu dingin $\left(4 \pm 3^{\circ} \mathrm{C}\right)$. Menurut Rohman et al. (2010), semakin rendah kadar pigmen karotenoid maka nilai kemerahan (a*) akan semakin kecil.

\section{Tingkat Kekuningan (b*)}

Hasil analisis ragam untuk nilai kekuningan $\left(b^{*}\right)$ menunjukkan bahwa perlakuan $\mathrm{pH}$ awal berpengaruh sangat nyata $(\mathrm{P}<0,01)$ pada setiap minggunya. Perlakuan suhu selama penyimpanan berpengaruh tidak nyata pada minggu ke-1 dan ke-3 $(\mathrm{P}>0,05)$ tetapi berpengaruh sangat nyata pada minggu ke-2 dan ke-4 $(\mathrm{P}<0,01)$. Interaksi kedua perlakuan menunjukkan pengaruh yang sangat nyata $(\mathrm{P}<0,01)$ pada setiap minggu selama penyimpanan. Nilai kekuningan $\left(b^{*}\right)$ ekstrak kulit buah jeruk Mandarin pada masing-masing perlakuan selama penyimpanan dapat dilihat pada Tabel 5.

Tabel 5. Nilai rata-rata tingkat kekuningan ( $\left.b^{*}\right)$ ekstrak kulit buah jeruk Mandarin pada perlakuan pH awal dan suhu selama penyimpanan pada minggu ke-1 sampai minggu ke-4.

\begin{tabular}{lllll}
\hline & \multicolumn{4}{c}{ Rata-rata nilai tingkat kekuningan $\left(\mathrm{b}^{*}\right) \pm \mathrm{SD}$} \\
\cline { 2 - 5 } \multicolumn{1}{c}{ Perlakuan } & Minggu 1 & Minggu 2 & Minggu 3 & Minggu 4 \\
\hline $\mathrm{pH} \mathrm{4;}\left(4 \pm 3^{\circ} \mathrm{C}\right)$ & $27,16 \pm 0,88 \mathrm{ab}$ & $23,83 \pm 0,23 \mathrm{~b}$ & $17,83 \pm 0,48 \mathrm{~d}$ & $16,14 \pm 0,36 \mathrm{c}$ \\
$\mathrm{pH} \mathrm{4;}\left(28 \pm 3^{\circ} \mathrm{C}\right)$ & $18,66 \pm 0,47 \mathrm{c}$ & $15,9 \pm 0,37 \mathrm{e}$ & $15,5 \pm 0,66 \mathrm{e}$ & $15,24 \pm 0,40 \mathrm{c}$ \\
$\mathrm{pH} \mathrm{7;}\left(4 \pm 3^{\circ} \mathrm{C}\right)$ & $28,25 \pm 0,36 \mathrm{a}$ & $27,11 \pm 0,53 \mathrm{a}$ & $26,87 \pm 0,46 \mathrm{a}$ & $26,56 \pm 0,55 \mathrm{a}$ \\
$\mathrm{pH} \mathrm{7;}\left(28 \pm 3^{\circ} \mathrm{C}\right)$ & $28,66 \pm 0,91 \mathrm{a}$ & $24,81 \pm 0,40 \mathrm{~b}$ & $24,56 \pm 0,84 \mathrm{~b}$ & $23,57 \pm 0,25 \mathrm{~b}$ \\
$\mathrm{pH} \mathrm{10}\left(4 \pm 3^{\circ} \mathrm{C}\right)$ & $19,19 \pm 0,43 \mathrm{c}$ & $18,92 \pm 0,30 \mathrm{~d}$ & $17,24 \pm 0,85 \mathrm{de}$ & $15,76 \pm 1,34 \mathrm{c}$ \\
$\mathrm{pH} \mathrm{10} ;\left(28 \pm 3^{\circ} \mathrm{C}\right)$ & $26,64 \pm 0,19 \mathrm{~b}$ & $20,75 \pm 0,87 \mathrm{c}$ & $20,24 \pm 0,85 \mathrm{c}$ & $15,53 \pm 0,28 \mathrm{c}$ \\
\hline
\end{tabular}

Keterangan: Angka yang diikuti huruf yang berbeda pada kolom yang sama menunjukkan berbeda nyata $(\mathrm{P}<0,05)$. Data merupakan rata-rata dari tiga ulangan pada masing-masing perlakuan.

Tabel 5 menunjukkan bahwa nilai tingkat kekuningan $\left(b^{*}\right)$ pada ekstrak kulit buah jeruk Mandarin pada masing-masing perlakuan mengalami penurunan setiap minggunya. Nilai tingkat kekuningan $\left(b^{*}\right)$ menunjukkan intensitas warna dari biru hingga kuning. Nilai kekuningan minggu ke0 pada ekstrak kulit buah jeruk Mandarin yang diperoleh adalah sebesar 32,77. Pengamatan nilai tingkat kekuningan $\left(b^{*}\right)$ ekstrak pewarna dari kulit buah jeruk
Mandarin menunjukkan bahwa semua perlakuan $\mathrm{pH}$ awal dan suhu selama penyimpanan mengakibatkan penurunan pada nilai tingkat kekuningan $\left(b^{*}\right)$ selama 4 minggu penyimpanan. Penurunan nilai tingkat kekuningan $\left(\mathrm{b}^{*}\right)$ untuk masing-masing perlakuan yaitu $\mathrm{pH} 4 ;\left(4 \pm 3^{\circ} \mathrm{C}\right), \mathrm{pH} 4 ;\left(28 \pm 3^{\circ} \mathrm{C}\right)$, $\mathrm{pH} 7 ;\left(4 \pm 3^{\circ} \mathrm{C}\right), \mathrm{pH} 7 ;\left(28 \pm 3^{\circ} \mathrm{C}\right), \mathrm{pH} 10 ;\left(4 \pm 3^{\circ} \mathrm{C}\right)$, dan $\mathrm{pH} 10 ;\left(28 \pm 3^{\circ} \mathrm{C}\right)$ dari kontrol hingga minggu keempat berturut-turut adalah 45,23\%; $47,67 \% ; 16,89 \% ; 25,02 \% ; 46,26 \%$; dan 
46,89\%. Perlakuan $\mathrm{pH} 7$ dengan penyimpanan suhu dingin $\left(4 \pm 3^{\circ} \mathrm{C}\right)$ menunjukkan penurunan nilai tingkat kekuningan paling kecil yaitu $16,89 \%$.

Kandungan pigmen karotenoid ekstrak kulit buah jeruk Mandarin yang paling tinggi yaitu pada perlakuan $\mathrm{pH}$ awal 7 dengan penyimpanan suhu dingin $\left(4 \pm 3^{\circ} \mathrm{C}\right)$ sehingga menghasilkan tingkat kekuningan yang paling tinggi dibandingkan perlakuan lainya. Semakin tinggi kandungan karotenoid dalam ekstrak maka nilai tingkat kekuningan juga semakin tinggi (Satriyanto et al., 2012). Hal ini sesuai dengan penelitian Indriyani et al. (2018), yaitu ekstrak pewarna buah pandan menghasilkan kadar karotenoid dan tingkat kekuningan paling tinggi pada perlakuan $\mathrm{pH}$ awal 7 dengan penyimpanan suhu dingin $\left(4 \pm 3^{\circ} \mathrm{C}\right)$. Grafik penurunan nilai tingkat kekuningan $\left(b^{*}\right)$ dari kontrol hingga minggu ke-4 disajikan dalam Gambar 5.

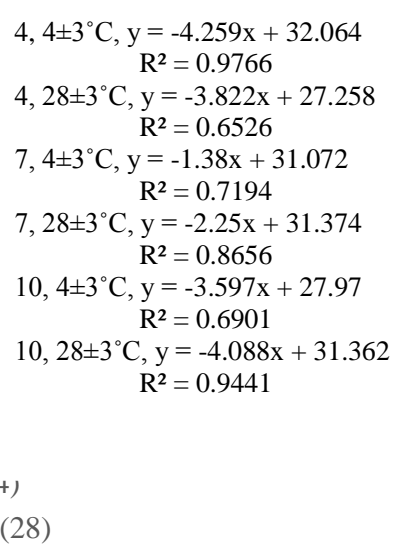

Gambar 5. Grafik penurunan nilai kekuningan $\left(b^{*}\right)$ ekstrak kulit buah jeruk Mandarin pada perlakuan $\mathrm{pH}$ awal dan suhu selama penyimpanan.

Gambar 5 menunjukkan model hubungan antara waktu penyimpanan dengan nilai tingkat kekuningan $\left(b^{*}\right)$ mempunyai nilai koefisien determinasi $\left(\mathrm{R}^{2}\right)$ berkisar antara 0,6526 sampai dengan 0,9766 . Hal ini menunjukkan bahwa waktu penyimpanan berpengaruh terhadap nilai tingkat kekuningan $\left(b^{*}\right)$ pada ekstrak pewarna kulit buah jeruk Mandarin. Nilai koefisien determinasi tertinggi sebesar 0,9766 diperoleh dari perlakuan $\mathrm{pH}$ awal 4 dengan penyimpanan suhu dingin $\left(4 \pm 3^{\circ} \mathrm{C}\right)$, yang artinya $97,66 \%$ nilai tingkat kekuningan $\left(b^{*}\right)$ dipengaruhi oleh waktu penyimpanan, dan $2,34 \%$ dipengaruhi faktor lain diantaranya zat kimia, oksigen, dan cahaya. Laju penurunan nilai tingkat kekuningan $\left(b^{*}\right)$ terkecil terdapat pada perlakuan $\mathrm{pH}$ awal 7 dengan penyimpanan suhu dingin $\left(4 \pm 3^{\circ} \mathrm{C}\right)$ yaitu sebesar 1,380 . Hal ini menunjukkan bahwa pigmen karotenoid yang terdapat dalam ekstrak pewarna dari kulit buah jeruk Mandarin stabil pada perlakuan tersebut dibandingkan dengan perlakuan lainnya. Hasil ini sesuai dengan laju penurunan kadar karotenoid paling kecil pada perlakuan $\mathrm{pH}$ awal 7 dengan penyimpanan suhu dingin $\left(4 \pm 3^{\circ} \mathrm{C}\right)$. Penurunan nilai tingkat kekuningan ini diakibatkan oleh pigmen karotenoid yang memberikan nilai kekuningan telah mengalami degradasi atau kerusakan. Pada perlakuan $\mathrm{pH}$ asam dan basa ekstrak kulit buah jeruk mandarin paling cepat terdegradasi.

\section{KESIMPULAN DAN SARAN}

\section{Kesimpulan}


Berdasarkan penelitian yang telah dilakukan maka dapat disimpulkan beberapa hal sebagai berikut:

1. Perlakuan $\mathrm{pH}$ awal dan suhu selama penyimpanan serta interaksinya berpengaruh terhadap total karotenoid, kapasitas antioksidan, nilai kecerahan $\left(\mathrm{L}^{*}\right)$, tingkat kemerahan $\left(\mathrm{a}^{*}\right)$, dan tingkat kekuningan $\left(b^{*}\right)$.

2. Ekstrak pewarna karotenoid dari kulit buah jeruk Mandarin paling stabil pada perlakuan $\mathrm{pH}$ awal 7 (netral) dan suhu dingin $\left(4 \pm 3^{\circ} \mathrm{C}\right)$ selama 4 minggu penyimpanan, dengan persentase penurunan total karotenoid, penurunan kapasitas antioksidan, kenaikan nilai L*, penurunan nilai $\mathrm{a}^{*}$, dan penurunan nilai $\mathrm{b}^{*}$ berturut-turut adalah sebesar $42,96 \%$; $21,02 \% ; 26,36 \%$; 20,89; dan 16,89\%.

\section{Saran}

Berdasarkan hasil penelitian ini dapat disarankan beberapa hal sebagai berikut :

1. Perlu dilakukan penelitian lebih lanjut mengenai senyawa yang dihasilkan dari proses degradasi ekstrak kulit buah jeruk Mandarin selama penyimpanan.

2. Ekstrak pewarna dari kulit buah jeruk Mandarin sebaiknya disimpan pada penyimpanan suhu dingin dan sebaiknya diaplikasikan pada produk yang memiliki pH netral.

\section{DAFTAR PUSTAKA}

Andriyani, M. D., E. N. Dewi, dan E. Susanto. 2016. Stabilitas ekstrak pigmen lamun laut (Enhalus acoroides) dari perairan teluk Awur Jepara terhadap suhu dan lama penyimpanan. Prosiding Seminar Nasional Hasil-Hasil Penelitian dan Kelautan. 6: 384-400.

Arimboor, R. dan R. B. Natarajan. 2015. Red pepper (Capsicum annuum) caretonoids as a sources of natural food colors: analysis and stability. J Food Sci Technol. 52 (3): 1258-1271.

Belitz, H. D., W. Grosch, and P. Schieberle. 2009. Food Chemistry. 4th Revised and Extended (Ed). Springer-Verlag Heidelberg, Berlin.

Claire, C. 1992. De la création d'une banque de données sur la composition biochimique des algues aux résultats d'une investigation systématique: un colorant naturel stable issu d'une Rhodophycée. PhD Thesis. Université de Nantes, Nantes.

de Fretes, H., A. B. Susanto, B. Prasetyo, dan L. Limantara. 2012. Karotenoid dari makroalgae dan mikroalgae: potensi kesehatan dan bioteknologi. Jurnal Teknol. dan Industri Pangan. 23 (2): 221228.

Indriyani, N. M. D., N. M. Wartini, N. P. Suwariani. 2018. Stabilitas karotenoid ekstrak pewarna buah pandan (Pandanus tectorius) pada suhu dan $\mathrm{pH}$ awal penyimpanan. Jurnal Rekayasa dan Manajemen Agroindustri. 6(3):211-217.

Ladislav, F., V. Pacakova, K. Stulik, and K. Volka. 2005. Reliability of carotenoid analysis: A Riview. Current Analitical Chemistry. 1: 93-102.

Lin, C. H. dan B. H. Chen. 2005. Stability of carotenoids in tomato juice during storage. Food Chemistry. 90 : 837-846.

Lubis, E. H., H. Wijaya, dan N. Lestari. 2012. Mempelajari ekstraksi dan stabilitas total karotenoid, $\alpha$ dan $\beta$ cryptoxanthin dalam ekstrak buah merah (Pandanus conoidieus, Lamk). Jurnal Riset Teknologi Industri. 6 (12): 39-53.

Mondello, L., A. Casilli., P.Q. Tranchida., P. Dugo and G. Dugo. 2005. Comprehensive two dimensional GC for the analysis of citrus essential oils. 
Flavour and Fragrance Journal, 20: 136140.

Muchtadi, D. 1989. Evaluasi Nilai Gizi Pangan. Departemen Pendidikan dan Kebudayaan Direktorat Jenderal Pendidikan Tinggi Pusat Antar Universitas Pangan dan Gizi. Institut Pertanian Bogor, Bogor.

Oktafia, S. 2015. Pengaruh pH dan Intensitas Cahaya terhadap Kestabilan Ekstrak Karotenoid Kulit Buah Alkesa (Pouteria campechiana (Kunth.) Baehni). Skripsi S1. Tidak dipublikasikan. Fakultas Sains dan Matematika, Universitas Kristen Satya Wacana, Salatiga.

Parinussa, T. M. S. dan F. S. Rondonuwu. 2009. Analisis kandungan karotenoid buah merah (Pandanus conoideus Lam.) pada suhu pemanasan yang berbeda. Prosiding Seminar Nasional Kimia dan Pendidikan Kimia. 473-486.

Rodriguez and D. B. R. Amaya. 2001. A Guide to Carotenoid Analysis in Food. International Life Science Institute. Washington.

Saraswati, S. A. B. J., L. P. Wrasiati, dan N. M. Wartini. 2018. Karakteristik pewarna alami dari ekstrak kulit buah jeruk mandarin (Citrus reticulata) pada perbandingan pelarut etanol dan kloroform. Jurnal Rekayasa dan Manajemen Agroindustri 6(4):278-287.
Satriyanto, B., S. B. Widjanarko, dan Yunianta. 2012. Stabilitas warna ekstrak buah merah (Pandanus conoideus) terhadap pemanasan sebagai sumber potensial pigmen alami. J. Teknol Pertanian. 13 (3):157-168.

Silalahi, S. E., L. P. Wrasiati, dan A. A. M. D. Anggreni. 2015. Karakteristik bubuk ekstrak kulit buah jeruk mandarin (Citrus reticulata) pada perlakuan lama maserasi dan konsentrasi maltodekstrin. Jurnal Rekayasa dan Manajemen Agroindustri 3(1):73-81.

Wahyuni, D. T., dan S. B. Widjanarko. 2015. Pengaruh jenis pelarut dan lama ekstraksi terhadap ekstrak karotenoid labu kuning dengan metode gelombang ultrasonik. Jurnal Pangan dan Agroindustri. 3 (2): 390-401.

Weaver, C. 1996. The Food Chemistry Laboratory. CRC Press, Boca Raton, New York, London, Tokyo. 